\title{
PENGARUH PENGGUNAAN MEDIA PEMBELAJARAN AUDIO-VISUAL DENGAN MICROSOFT POWERPOINT TERHADAP KEAKTIFAN DAN PEMAHAMAN BELAJAR SISWA KELAS X PADA MATA PELAJARAN SOSIOLOGI DI MA NU ISLAMIYAH ASEMBAGUS
}

\author{
Firman Jaya S.Pt ${ }^{1 *}$, M.Kom, Linda Arnilya, S.Pd ${ }^{2^{*}}$ \\ STKIP PGRI Situbondo \\ altamis1922@gmail.com
}

\begin{abstract}
ABSTRAK
Peningkatan kualitas proses pembelajaran siswa disetiap jenjang pendidikan perlu diwujudkan agar diperoleh kualitas sumber daya manusia yang dapat menunjang pembangunan nasional dinegara Indonesia. Salah satu upaya untuk meningkatkan upaya tersebut yaitu dengan meningkatkan keaktifan dan pemahaman belajar siswa dalam proses pembelajaran salah satunya dengan menggunakan media audio-visual dengan microsoft powerpoint Metode pembelajaran media non audio-visual dengan microsoft powerpoint yang menekankan pada guru untuk bercerita dan siswa mendengarkan harus lebih banyak dihindari agar keaktifan dan pemahaman siswa meningkat. Hasil penelitian menunjukkan bahwa: 1) pengaruh penggunaan media pembelajaran audio-visual dengan microsoft powerpoint $(\mathrm{X})$ terhadap keaktifan belajar siswa $\left(\mathrm{Y}_{1}\right)$ kelas $\mathrm{X}$ pada mata pelajaran sosiologi di MA NU Islamiyah Asembagus, diketahui bahwa nilai kelas X IPS 2 (Kelas Eksperimen) sebasar $(6,234)$ dengan tingkat pengaruh sempurna. Sedangkan pada kelas X IPS 1 (Kelas Kontrol) dengan nilai sebesar $(-0,099)$ yang berarti tidak ada pengaruh. 2) Pengaruh penggunaan media pembelajaran audio-visual dengan microsoft powerpoint $(\mathrm{X})$ terhadap pemahaman belajar siswa $\left(\mathrm{Y}_{2}\right)$ kelas $\mathrm{X}$ pada mata pelajaran sosiologi di MA NU Islamiyah Asembagus, diketahui bahwa nilai kelas X IPS 2 (Kelas Eksperimen) sebasar $(0,584)$ dengan tingkat pengaruh sedang. Sedangkan pada kelas $\mathrm{X}$ IPS 1 (Kelas Kontrol) dengan nilai sebesar $(0,309)$ dengan tingkat pengaruh rendah.
\end{abstract}

Kata Kunci : Media Pembelajaran Audio-Visual Dengan Microsoft Powerpoint, keaktifan dan Pemahaman Belajar Siswa. 


\begin{abstract}
Improving the quality of student learning at every level of education needs to be realized in order to obtain the quality of human resources that can support national development in the country of Indonesia. One effort to increase these efforts is to increase the activity and understanding of students learning in the learning process one of them by using audio-visual media with Microsoft PowerPoint. Non-audio-visual media learning methods with Microsoft PowerPoint that help teachers to tell a lot are improved so that students' activeness and understanding increase. The results showed that: 1) the influence of the use of audio-visual learning media with Microsoft PowerPoint (X) on the learning activeness of students ( $\mathrm{Y} 1$ ) class $\mathrm{X}$ on sociology subjects at MA NU Islamiyah Asembagus, it is known that the grade X IPS 2 (Experimental Class) sebasar $(6,234)$ with a perfect level of influence. While in class X IPS 1 (Control Class) with a value of (0,099) which means there is no influence. 2) The influence of the use of audio-visual learning media with Microsoft PowerPoint (X) on the understanding of student learning (Y2) class X on sociology subjects at MA NU Islamiyah Asembagus, it is known that the grade X IPS 2 (Experimental Class) is as much (0.584) as moderate level of influence. While in class X IPS 1 (Control Class) with a value of (0.309) with a low level of influence.
\end{abstract}

Keyword: Audio-Visual Learning Media With Microsoft Powerpoint, Active and Understanding Student Learning.

\title{
PENDAHULUAN
}

Belajar merupakan sebagai proses perubahan perilaku sebagai hasil interaksi individu dengan lingkungannya. Perubahan perilaku terhadap hasil belajar bersifat continue, fungsional, positif, aktif, dan terarah. Proses perubahan tingkah laku dapat terjadi dalam berbagai kondisi berdasarkan penjelasan dari para ahli pendidikan dan psikologi. Adapun pembelajaran adalah proses interaksi peserta didik dengan pendidik, dengan bahan pelajaran, metode penyampaian, strategi pembelajaran, dan sumber belajar dalam suatu lingkungan belajar (dalam jurnal penelitian Aprida Pane \& Muhammad Darwis Dasopang: 2017).

Pentingnya keaktifan dan Pemahaman belajar siswa pada sebuah materi pelajaran maka diperlukan pemilihan model pembelajaran yang tepat untuk membantu meningkatkan Pemahaman dan pemahaman belajar siswa. Salah satunya dengan menggunakan audio-visual dengan Microsoft PowerPoint (dalam Jurnal penelitian Wawan Suseno, Ipung Yuwono, Gatot Muhsetyo: Oktober 2017). Dalam hal ini peran seorang guru sangat penting dan menentukan, sebab gurulah yang terlibat langsung untuk membina dan mengajari para siswa disekolah melalui proses pembelajaran.

\section{METODE PENELITIAN}

Penelitian ini dilaksanakan di MA NU Islamiyah Asembagus yang beralamat di Jalan Raya No. 170 Asembagus. Peneliti menggunakan metode 
pendekatan Kuantitatif. Menurut Prof. Dr. Sugiyono (2018: 72) Peneliti menggunakan metode penelitian eksperien (Experimental research) dan penelitian kontrol yang bertujuan untuk menguji pengaruh media pembelajaran audio-visual dengan Microsoft Power Point terhadap Pemahaman dan pemahaman belajar siswa kelas X pada mata pelajaran Sosiologi.

Populasi dalam penelitian ini adalah seluruh kelas X MA NU Islamiyah Asembagus. Menggunakan teknik non probability sampling dengan tidak memberi peluang atau kesempatan sama bagi setiap unsur atau anggota populasi untuk dipilih menjadi sampel. Cara pengambilannya menggunakan Sampling Jenuh yakni teknik penentuan sampel bila semua anggota populasi digunakan sebagai sampel. Maka sampel penelitian ini adalah kelas X MA NU Islamiyah Asembagus yang terbagi dua kelas. siswa kelas X IPS 2 (kelas eksperimen) dan kelas X IPS 1 (kelas kotrol).

Teknik pengumpulan data pada penelitian ini sebagai dengan Observasi, Interview, Metode angket dan Dokumentasi. Untuk mengetahui seberapa pengaruh variabel $X$ terhadap variabel $Y_{1}$ dan variabel $X$ terhadap variabel $Y_{2}$ maka dilakukan teknik analisis data dengan menggunakan uji validitas dan analisis regresi.

\section{Uji Validitas}

Uji validitas dari suatu pertanyaan yang digunakan dalam pengumpulan data dengan cara mengkorelasikan setiap nilai variabel jawaban dari responden dengan jumlah nilai setiap variabel. Selanjutnya nilai dari korelasi dibandingkan dengan nilai kritis signifikan 0,05. Adapun rumus uji validasi sebagai berikut:

$$
\mathrm{r}_{\mathrm{xy}}=\frac{\mathrm{n} \sum \mathrm{xy}_{1} \mathrm{y}_{2}-\left(\sum \mathrm{x}\right)\left(\sum \mathrm{y}_{1}\right)\left(\sum \mathrm{y}_{2}\right)}{\sqrt{\mathrm{n}\left[\sum \mathrm{x}^{2}-\left(\sum \mathrm{x}\right)^{2}\right]\left[\mathrm{n}\left(\Sigma \mathrm{y}_{1}{ }^{2}\right)-\left(\sum \mathrm{y}_{1}\right)^{2}\right]\left[\mathrm{n}\left(\sum \mathrm{y}_{2}{ }^{2}\right)-\left(\sum \mathrm{y}_{2}\right)^{2}\right]}}
$$

Keterangan:

$\mathrm{r}_{\mathrm{xy}} \quad=$ Koefisien korelasi

$x \quad=$ Skor pertanyaan tiap nomor

$y=$ Jumlah skor total pertanyaan

$n \quad=$ Jumlah responden

Adapun proses perhitungan dilakukan dengan cara menggunakan program aplikasi SPSS (Statistic Product And Service Solution) 24.0 for Windows.

\section{2) Analisis Regresi}

Jika data terdistribusi normal maka pengujian hipotesis dalam penelitian ini menggunakan analisis regresi sederhana, dengan bantuan program SPSS (Statistic Product And Service Solution) 24.0 for Windows.

\section{1) Persamaan Garis Regresi Linear Sederhana sebagai berikut:}

$$
\begin{aligned}
& Y_{1}=a_{1}+b_{1} X \\
& Y_{2}=a_{2}+b_{2} X
\end{aligned}
$$


Keterangan:

$\mathrm{Y}_{1} \quad=$ Variabel terikat untuk (Pemahaman belajar siswa)

$\mathrm{Y}_{2} \quad=$ Variabel terikat untuk (pemahaman belajar siswa)

$\mathrm{X}=$ Variabel bebas

$\mathrm{a} \quad=$ Konstanta

$\mathrm{b} \quad=$ Koefisien regresi

2) Menghitung Koefisien Korelasi

Maka digunakan rumus Korelasi Product Moment sebagai berikut:

$\mathrm{r}_{\mathrm{xy}}=\frac{\mathrm{n} \sum \mathrm{xy}_{1} \mathrm{y}_{2}-\left(\sum \mathrm{x}\right)\left(\sum \mathrm{y}_{1}\right)\left(\sum \mathrm{y}_{2}\right)}{\sqrt{\mathrm{n}\left[\sum \mathrm{x}^{2}-\left(\sum \mathrm{x}\right)^{2}\right]\left[\mathrm{n}\left(\Sigma \mathrm{y}_{1}{ }^{2}\right)-\left(\sum \mathrm{y}_{1}\right)^{2}\right]\left[\mathrm{n}\left(\Sigma \mathrm{y}_{2}{ }^{2}\right)-\left(\sum \mathrm{y}_{2}\right)^{2}\right]}}$

Keterangan:

$\mathrm{r}_{\mathrm{xy}} \quad=$ Koefisien korelasi

$x=$ Skor pertanyaan tiap nomor

$y \quad=$ Jumlah skor total pertanyaan

$n \quad=$ Jumlah responden

Hasil analisis statistika dengan menggunakan perhitungan koefisien korelasi dapat dilihat pada tabel interpretasi koefisien korelasi sebagai berikut:

\section{3) Menghitung Analisa Variasi Garis Regresi}

$$
F_{\text {reg }}=\frac{R^{2}(N-m-1)}{m\left(1-R^{2}\right)}
$$

Keterangan:

$\mathrm{R}^{2} \quad=$ Koefisien korelasi variabel bebas terhadap variabel terikat

$\mathrm{N} \quad=$ Banyaknya anggota sampel

$\mathrm{m} \quad=$ Jumlah variabel bebas

4) Menghitung Efektifitas Garis Regresi (EGR)

$E G R=\frac{J K_{\text {rgg }}}{J K_{\text {total }}} \times 100 \%$

Keterangan:

$\mathrm{JK}_{\text {reg }} \quad=$ Jumlah kuadrat regresi

$\mathrm{JK}_{\text {total }}=$ Jumlah kuadrat total

\section{HASIL DAN PEMBAHASAN}

\section{A. Hasil Uji Validitas}

Setelah dilakukan uji validitas melalui komputer untuk media pembelajaran audio-visual dengan Microsoft PowerPoint terhadap Pemahaman dan pemahaman belajar siswa dengan menggunakan SPSS (Statistical Product and service Solution) 24.0 for windows. 
Tabel. Hasil Uji Validitas Kelas Eksperimen

\begin{tabular}{cccccc}
\hline No. & Variabel & $\begin{array}{c}\text { Total Korelasi / } \\
\mathbf{r}_{\text {hitung }}\end{array}$ & $\mathbf{r}_{\text {tabel }}$ & Sig. & Kriteria \\
\hline 1. & Variabel (X) dan $\left(\mathrm{Y}_{1}\right)$ & 6,234 & 0,482 & 0,000 & Valid \\
2. & Variabel (X) dan $\left(\mathrm{Y}_{2}\right)$ & 0,584 & 0,482 & 0,000 & Valid \\
\hline
\end{tabular}

Berdasarkan tabel 4.1 dapat dilihat bahwa seluruh pertanyaan untuk Kelas Eksperimen memiliki status valid, karena nilai $r_{\text {hitung }}>r_{\text {tabel }}$ sebesar 0,482.

Tabel. Hasil Uji Validitas Kelas Kontrol

\begin{tabular}{cccccc}
\hline No. & Variabel & $\begin{array}{c}\text { Total Korelasi } \\
/ \mathbf{r}_{\text {hitung }}\end{array}$ & $\mathbf{r}_{\text {tabel }}$ & Sig. & Kriteria \\
\hline 1 & Variabel (X) dan $\left(\mathrm{Y}_{1}\right)$ & $-0,099$ & 0,514 & 0,000 & $\begin{array}{c}\text { Tidak } \\
\text { Valid }\end{array}$ \\
& Variabel (X) dan ( $\left.\mathrm{Y}_{2}\right)$ & 0,309 & 0,514 & 0,000 & $\begin{array}{c}\text { Tidak } \\
\text { Valid }\end{array}$ \\
\hline
\end{tabular}

Berdasarkan tabel 4.2 dapat dilihat bahwa seluruh pertanyaan untuk Kelas Kontrol memiliki status tidak valid, karena nilai $r_{\text {hitung }}<r_{\text {tabel }}$ sebesar 0,514.

a. Pengaruh Media Pembelajaran Audio-Visual Dengan Microsoft Powerpoint Terhadap Keaktifan Dan Pemahaman Belajar Siswa Kelas X IPS 2 (Kelas Eksperimen).

\section{1). Persamaan Garis Regresi}

Persamaan garis regresi linear dilakuakan dengan koefisien prediktor (b) dan bilangan konstanta (a) sebagai berikut:

a. Menghitung pengaruh media pembelajaran audio-visual dengan microsoft powerpoint $(\mathrm{X})$ terhadap keaktifan belajar siswa $\left(\mathrm{Y}_{1}\right)$. Dengan rumus $\mathrm{Y}_{1}=\mathrm{a}_{1}+\mathrm{b}_{1} \mathrm{X}$, maka mendapatkan hasil $\mathrm{Y}_{1}=$ $-38,652,632+0,158617818$

b. Menghitung pengaruh media pembelajaran audio-visual dengan microsoft powerpoint $(\mathrm{X})$ terhadap pemahaman belajar siswa $\left(\mathrm{Y}_{2}\right)$. Dengan rumus $Y_{2}=a_{2}+b_{2} X$ Jadi, hasil yang diperoleh dari persamaan garis regresi adalah:

$Y_{2}=21,9526316+0,5095755354$

\section{2) Menghitung Koefisien Korelasi}

Untuk mengetahui besarnya pengaruh antara variabel $(\mathrm{X})$ dengan variabel $\left(\mathrm{Y}_{1}\right.$ dan $\left.\mathrm{Y}_{2}\right)$, maka digunakan rumus Korelasi Product Moment dengan rumus sebagai berikut:

$r_{x y}=\frac{n \sum x_{1} y_{2}-\left(\sum x\right)\left(\Sigma y_{1}\right)\left(\sum y_{2}\right)}{\sqrt{\left[n\left(\sum x^{2}\right)-\left(\sum x\right)^{2}\right]\left[n\left(\Sigma y_{1}^{2}\right)-\left(\Sigma y_{1}\right)^{2}\right]\left[n\left(\Sigma y_{2}^{2}\right)-\left(\Sigma y_{2}\right)^{2}\right]}}$

1. Menghitung pengaruh media pembelajaran audio-visual dengan microsoft powerpoint $(\mathrm{X})$ terhadap keaktifan belajar siswa $\left(\mathrm{Y}_{1}\right)$. 


$$
\begin{aligned}
& \mathrm{r}_{\mathrm{xy}}=\frac{\mathrm{n} \sum \mathrm{xy}_{1}-\left(\sum \mathrm{x}\right)\left(\sum \mathrm{y}_{1}\right)}{\sqrt{\left[\mathrm{n}\left(\sum \mathrm{x}^{2}-\left(\sum \mathrm{x}\right)^{2}\right]\left[\mathrm{n}\left(\Sigma \mathrm{y}_{1}{ }^{2}\right)-\left(\sum \mathrm{y}_{1}\right)^{2}\right]\right.}} \text { dengan hasil : } \\
& \mathrm{r}_{\mathrm{xy}} \mathrm{r}_{\mathrm{xy}}=\frac{10381}{1665,19188} \\
& r_{x y}=6,2341164 \\
& \mathrm{r}_{\mathrm{xy}}^{2}=3,886
\end{aligned}
$$

2. Menghitung pengaruh media pembelajaran audio-visual dengan microsoft powerpoint $(\mathrm{X})$ terhadap pemahaman belajar siswa $\left(\mathrm{Y}_{2}\right)$.

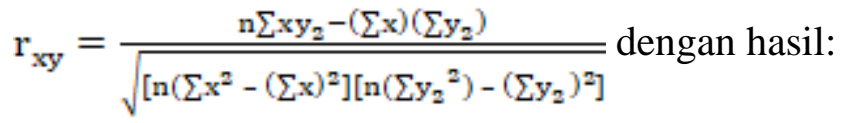

$r_{\mathrm{xy}}=\frac{1224}{2095,69}$

$r_{x y}=0,584055848$

$r_{x y}^{2}=0,341$

\section{3) Menghitung Analisa Variasi Garis Regresi}

1. Menghitung pengaruh media pembelajaran audio-visual dengan microsoft powerpoint $(\mathrm{X})$ terhadap Keaktifan belajar siswa $\left(\mathrm{Y}_{1}\right)$. Untuk mengetahui apakah nilai $\mathrm{r}_{\mathrm{xy}}=6$,234Signifikan atau tidak, maka dilakukan analisis

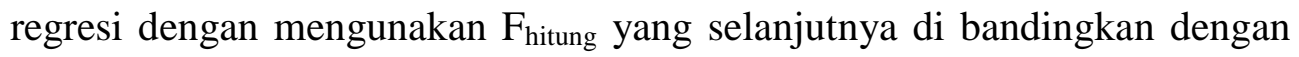
hasil $\mathrm{F}_{\text {tabel. }}$.

$$
\begin{aligned}
& F_{\text {reg }}=\frac{R^{2}(N-m-1)}{m\left(1-R^{2}\right)} \text { dengan hasil : } \\
& F_{\text {reg }}=F_{\text {reg }}=17,004375
\end{aligned}
$$

Dengan rumus tersebut dan memasukkan data-data yang ada. Maka, diperoleh nilai $F_{\text {reg }}=17,004375$, untuk mengetahui signifikan atau tidaknya nilai $F_{\text {hitung }}$ di bandingkan dengan hasil $F_{\text {tabel. }}$. Derajat kebebasan untuk menguji signifikansi nilai $F_{\text {reg }}$ adalah $\mathrm{m}(\mathrm{N}-\mathrm{m}-1)$ dalam kasus ini dalam $\mathrm{db}=1 / 17$ dengan taraf signifikan $5 \%=4,451$, jadi nilai $\mathrm{F}_{\text {reg }}=17,004375$ ini signifikan yang berarti hipotesis $\left(\mathrm{H}_{0}\right)$ di tolak dan hipotesis $\left(\mathrm{H}_{\mathrm{a}}\right)$ diterima. Untuk lebih jelasnya dapat dilihat pada tabel perbadingan dibawah ini:

Tabel. Perbandingan $F_{\text {hitung }}$ dengan $F_{\text {tabel }}$ pada variabel $(X)$ dan $\left(Y_{1}\right)$

\begin{tabular}{cccccc}
\hline Hipotesis & $\mathbf{F}_{\text {hitung }}$ & $\mathbf{F}_{\text {tabel }}$ & $\begin{array}{c}\text { Keputusan } \\
\text { statistik }\end{array}$ & Korelasi & $\begin{array}{c}\text { Keputusan } \\
\text { akhir }\end{array}$ \\
\hline $\mathrm{H}_{0}$ & - & - & - & - & $\mathrm{H}_{0}$ ditolak \\
$\mathrm{H}_{\mathrm{a}}$ & 17,004375 & 4,451 & Signifikan & Berpengaruh & $\mathrm{H}_{\mathrm{a}}$ diterima \\
\hline \multicolumn{7}{c}{$\begin{array}{c}\text { 1. } \\
\text { Menghitung } \\
\text { microsoft powerpoint }(\mathrm{X}) \text { terhadap pemahaman belajar siswa }\left(\mathrm{Y}_{2}\right) .\end{array}$}
\end{tabular}


Untuk menegtahui nilai $r_{x y}=0,584$ Signifikan atau tidak, maka dilakukan analisis regresi dengan mengunakan $F_{\text {hitung }}$ yang selanjutnya di bandingkan dengan hasil $\mathrm{F}_{\text {tabel }}$.

$F_{\text {reg }}=\frac{R^{2}(N-m-1)}{m\left(1-R^{2}\right)}$ dengan hasil :

$F_{\text {reg }}=F_{\text {reg }}=8,79666161$

Dengan rumus tersebut dan memasukkan data-data yang ada. Maka, diperoleh nilai $\mathrm{F}_{\text {reg }}=8,79666161$, untuk mengetahui signifikan atau tidaknya nilai $F_{\text {hitung }}$ di bandingkan dengan hasil $F_{\text {tabel }}$. Derajat kebebasan untuk menguji signifikansi nilai $F_{\text {reg }}$ adalah $\mathrm{m}(\mathrm{N}-\mathrm{m}-1)$ dalam kasus ini dalam $\mathrm{db}=1 / 17$ dengan taraf signifikan $5 \%=4,451$, jadi nilai $\mathrm{F}_{\text {reg }}=8,79666161$ ini signifikan yang berarti hipotesis $\left(\mathrm{H}_{0}\right)$ di tolak dan hipotesis $\left(\mathrm{H}_{\mathrm{a}}\right)$ diterima. Untuk lebih jelasnya dapat dilihat pada tabel perbadingan dibawah ini:

Tabel. Perbandingan $F_{\text {hitung }}$ dengan $F_{\text {tabel }}$ pada variabel $(X)$ dan $\left(Y_{2}\right)$

\begin{tabular}{cccccc}
\hline Hipotesis & $\mathbf{F}_{\text {hitung }}$ & $\mathbf{F}_{\text {tabel }}$ & $\begin{array}{c}\text { Keputusan } \\
\text { statistik }\end{array}$ & Korelasi & $\begin{array}{c}\text { Keputusan } \\
\text { akhir }\end{array}$ \\
\hline $\mathrm{H}_{0}$ & - & - & - & - & $\mathrm{H}_{0}$ ditolak \\
$\mathrm{H}_{\mathrm{a}}$ & 8,79666161 & 4,451 & Signifikan & Berpengaruh & $\mathrm{H}_{\mathrm{a}}$ diterima \\
\hline
\end{tabular}

\section{4)Menghitung Efektifitas Garis Regresi (EGR)}

Efektifitas Garis Regresi (EGR) adalah garis yang menunjukkan berapa garis regresi yang dapat digunakan untuk mengetahui berapa persen $(\%)$ pengaruh variabel $(\mathrm{X})$ terhadap variabel $\left(\mathrm{Y}_{1}\right)$ dan $\left(\mathrm{Y}_{2}\right)$. Adapun rumusnya sebagai berikut:

Efektifitas Garis Regresi $(E G R)=\frac{J K_{\text {reg }}}{J K_{\text {total }}} \times 100 \%$

a. Menghitung pengaruh media pembelajaran audio-visual dengan microsoft powerpoint $(\mathrm{X})$ terhadap Keaktifan belajar siswa $\left(\mathrm{Y}_{1}\right)$.

$$
\begin{aligned}
& I K_{\text {total }}=\sum Y_{1}^{2}-\frac{\left(\sum Y_{1}\right)^{2}}{N} \\
& I K_{\text {total }}=12339-\frac{(483)^{2}}{19} \\
& I K_{\text {total }}=60,6316 \\
& I K_{\text {reg }}=b_{1}\left(\sum X Y_{1}\right)+a_{1}\left(\sum Y_{1}\right)-\frac{\left(\sum Y_{1}\right)^{2}}{N} \\
& I K_{\text {reg }}=0,158617818(11790)+(-38652632)(483)-\frac{(483)^{2}}{19} \\
& (E G R)=\frac{J K_{\text {reg }}}{J K_{\text {total }}} \times 100 \%
\end{aligned}
$$




$$
\begin{aligned}
& (E G R)=\frac{18,792003070}{606316} \times 100 \% \\
& E G R=30,993 \%
\end{aligned}
$$

b. Menghitung pengaruh media pembelajaran audio-visual dengan microsoft powerpoint $(\mathrm{X})$ terhadap pemahaman belajar siswa $\left(\mathrm{Y}_{2}\right)$.

$$
\begin{aligned}
& I K_{\text {total }}=\sum Y_{2}^{2}-\frac{\left(\sum Y_{2}\right)^{2}}{N} \\
& J K_{\text {total }}=22551-\frac{(653)^{2}}{19} \\
& I K_{\text {total }}=10,879 \\
& I K_{\text {reg }}=b_{2}\left(\sum X Y_{2}\right)+a_{2}\left(\sum Y_{2}\right)-\frac{\left(\sum Y_{2}\right)^{2}}{N} \\
& I K_{\text {reg }}=0,5095755354(15977)+(21,9526316)(653)-\frac{(653)^{2}}{19} \\
& I K_{\text {reg }}=149.247,916 \\
& (E G R)=\frac{J K_{\text {reg }}}{J K_{\text {total }}} \times 100 \% \\
& (E G R)=\frac{149.247,916}{10,879} \times 100 \% \\
& E G R=13,71 \%
\end{aligned}
$$

C. Pengaruh Media Pembelajaran Audio-Visual Dengan Microsoft Powerpoint Terhadap Keaktifan Dan pemahaman Belajar Siswa Kelas X IPS 1 (Kelas Kontrol).

\section{Persamaan Garis Regresi}

Persamaan garis regresi linear dilakuakan dengan koefisien prediktor

(b) dan bilangan konstanta (a) sebagai berikut:

a. Menghitung pengaruh media pembelajaran audio-visual dengan microsoft powerpoint $(\mathrm{X})$ terhadap keaktifan belajar siswa $\left(\mathrm{Y}_{1}\right)$.

$\mathrm{Y}_{1}=\mathrm{a}_{1}+\mathrm{b}_{1} \mathrm{X}$

Dimana:

$b_{1}=\frac{N\left(\Sigma X Y_{1}\right)-(\Sigma x)\left(\Sigma Y_{1}\right)}{N\left(\Sigma x^{2}\right)-(\Sigma x)^{2}}$ dengan hasil:

$b_{1}=\frac{-163}{1509}$

$b_{1}=-0,108$

$a_{1}=\frac{\left(\Sigma Y_{1}\right)-b_{1}(\Sigma x)}{N}$ dengan hasil :

$a_{1}=17,034$

Jadi, hasil persamaan garis regresi yaitu: $\mathrm{Y}_{1=17,034-0,108}$ 
b. Menghitung pengaruh media pembelajaran audio-visual dengan microsoft powerpoint $(\mathrm{X})$ terhadap pemahaman belajar siswa $\left(\mathrm{Y}_{2}\right)$.

$\mathrm{Y}_{2}=\mathrm{a}_{2}+\mathrm{b}_{2} \mathrm{X}$

Dimana:

$b_{2}=\frac{N\left(\Sigma X Y_{2}\right)-(\Sigma X)\left(\Sigma Y_{2}\right)}{N\left(\Sigma X^{2}\right)-(\Sigma x)^{2}}$ dengan hasil:

$b_{2}=0,316$

$a_{2}=\frac{\left(\Sigma Y_{2}\right)-b_{2}(\Sigma X)}{N}$ dengan hasil:

$a_{2}=17,377$

Jadi, hasil persamaan garis regresi adalah: $Y_{2}=17,377+0,316$

\section{Menghitung Koefisien Korelasi}

Untuk mengetahui besarnya pengaruh antara variabel $(\mathrm{X})$ dengan variabel $\left(\mathrm{Y}_{1}\right.$ dan $\mathrm{Y}_{2}$ ), maka digunakan rumus Korelasi Product Moment dengan rumus sebagai berikut:

$$
\mathrm{r}_{\mathrm{xy}}=\frac{\mathrm{n} \sum \mathrm{xy}_{1} \mathrm{y}_{2}-\left(\sum \mathrm{x}\right)\left(\sum \mathrm{y}_{1}\right)\left(\sum \mathrm{y}_{2}\right)}{\sqrt{\left[\mathrm{n}\left(\sum \mathrm{x}^{2}\right)-\left(\sum \mathrm{x}\right)^{2}\right]\left[\mathrm{n}\left(\Sigma \mathrm{y}_{1}{ }^{2}\right)-\left(\Sigma \mathrm{y}_{1}\right)^{2}\right]\left[\mathrm{n}\left(\Sigma \mathrm{y}_{2}{ }^{2}\right)-\left(\Sigma y_{2}\right)^{2}\right]}}
$$

a. Menghitung pengaruh media pembelajaran audio-visual dengan microsoft powerpoint $(\mathrm{X})$ terhadap keaktifan belajar siswa $\left(\mathrm{Y}_{1}\right)$.

$\mathrm{r}_{\mathrm{xy}}=\frac{\mathrm{n} \Sigma \mathrm{xy}_{1}-\left(\sum \mathrm{x}\right)\left(\sum \mathrm{y}_{1}\right)}{\sqrt{\left[\mathrm{n}\left(\Sigma \mathrm{x}^{\mathrm{s}}-\left(\sum \mathrm{x}\right)^{2}\right]\left[\mathrm{n}\left(\Sigma \mathrm{y}_{1}{ }^{2}\right)-\left(\sum \mathrm{y}_{1}\right)^{2}\right]\right.}}$ dengan hasil ${ }_{\mathrm{xy}}^{2}=0,009$

b. Menghitung pengaruh media pembelajaran audio-visual dengan microsoft powerpoint $(\mathrm{X})$ terhadap pemahaman belajar siswa $\left(\mathrm{Y}_{2}\right)$.

$$
\begin{aligned}
& \mathrm{r}_{\mathrm{xy}}=\frac{\mathrm{n} \sum \mathrm{xy}_{\mathrm{z}}-\left(\sum \mathrm{x}\right)\left(\sum \mathrm{y}_{2}\right)}{\sqrt{\left[\mathrm{n}\left(\Sigma \mathrm{x}^{2}-\left(\sum \mathrm{x}\right)^{2}\right]\left[\mathrm{n}\left(\Sigma \mathrm{y}_{2}{ }^{2}\right)-\left(\sum \mathrm{y}_{\mathrm{z}}\right)^{2}\right]\right.}} \text { dengan hasil: } \\
& r_{x y}=0,309 \\
& \mathrm{r}_{\mathrm{xy}}^{2}=0,095
\end{aligned}
$$

\section{Menghitung Analisa Variasi Garis Regresi}

1. Menghitung pengaruh media pembelajaran audio-visual dengan microsoft powerpoint $(\mathrm{X})$ terhadap keaktifan belajar siswa $\left(\mathrm{Y}_{1}\right)$.

Untuk mengetahui apakah nilai $r_{x y}=-0,099$ Signifikan atau tidak, maka dilakukan analisis regresi dengan mengunakan $F_{\text {hitung }}$ yang selanjutnya di bandingkan dengan hasil $\mathrm{F}_{\text {tabel }}$.

$F_{r e g}=\frac{R^{2}(N-m-1)}{m\left(1-R^{2}\right)}$ dengan hasil $F_{r e g}=0,136$

Dengan rumus tersebut dan memasukkan data-data yang ada. Maka, diperoleh nilai $\mathrm{F}_{\text {reg }}=0,136$, untuk mengetahui signifikan atau tidaknya nilai $F_{\text {hitung }}$ di bandingkan dengan hasil $F_{\text {tabel }}$. Derajat kebebasan 
untuk menguji signifikansi nilai $\mathrm{F}_{\text {reg }}$ adalah $\mathrm{m}(\mathrm{N}-\mathrm{m}-1)$ dalam kasus ini dalam $\mathrm{db}=1 / 15$ dengan taraf signifikan $5 \%=4,543$, jadi nilai $\mathrm{F}_{\text {reg }}=$ 0,136 ini signifikan yang berarti hipotesis $\left(\mathrm{H}_{0}\right)$ di tolak dan hipotesis $\left(\mathrm{H}_{\mathrm{a}}\right)$ diterima. Untuk lebih jelasnya dapat dilihat pada tabel perbandingan dibawah ini:

Tabel. Perbandingan $F_{\text {hitung }}$ dengan $F_{\text {tabel }}$ pada variabel $(X)$ dan $\left(Y_{1}\right)$

\begin{tabular}{cccccc}
\hline Hipotesis & F $_{\text {hitung }}$ & $\mathbf{F}_{\text {tabel }}$ & $\begin{array}{c}\text { Keputusan } \\
\text { statistik }\end{array}$ & Korelasi & $\begin{array}{c}\text { Keputusan } \\
\text { akhir }\end{array}$ \\
\hline $\mathrm{H}_{0}$ & - & 4,543 & - & - & $\mathrm{H}_{0}$ diterima \\
$\mathrm{H}_{\mathrm{a}}$ & 0,136 & 4,543 & Tidak Sig. & Tidak ada pengaruh & $\mathrm{H}_{\mathrm{a}}$ ditolak \\
\hline
\end{tabular}

2. Menghitung pengaruh media pembelajaran audio-visual dengan microsoft powerpoint $(\mathrm{X})$ terhadap pemahaman belajar siswa $\left(\mathrm{Y}_{2}\right)$.

Untuk menegtahui nilai $r_{x y}=0,309$ Signifikan atau tidak, maka dilakukan analisis regresi dengan mengunakan $F_{\text {hitung }}$ yang selanjutnya di bandingkan dengan hasil $\mathrm{F}_{\text {tabel }}$.

$F_{r e g}=\frac{R^{2}(N-m-1)}{m\left(1-R^{2}\right)}$ dengan hasil $F_{r e g}=1,574$

Dengan rumus tersebut dan memasukkan data-data yang ada. Maka, diperoleh nilai $F_{\text {reg }}=1,574$, untuk mengetahui signifikan atau tidaknya nilai $\mathrm{F}_{\text {hitung }}$ di bandingkan dengan hasil $\mathrm{F}_{\text {tabel }}$. Derajat kebebasan untuk menguji signifikansi nilai $F_{\text {reg }}$ adalah $m(N-m-1)$ dalam kasus ini dalam $\mathrm{db}=1 / 15$ dengan taraf signifikan $5 \%=4,543$, jadi nilai $\mathrm{F}_{\text {reg }}=$ 1,574 ini signifikan yang berarti hipotesis $\left(\mathrm{H}_{0}\right)$ di tolak dan hipotesis $\left(\mathrm{H}_{\mathrm{a}}\right)$ diterima. Untuk lebih jelasnya dapat dilihat pada tabel perbadingan dibawah ini:

Tabel. Perbandingan $F_{\text {hitung }}$ dengan $F_{\text {tabel }}$ pada variabel $(X)$ dan $\left(Y_{2}\right)$

\begin{tabular}{cccccc}
\hline Hipotesis & $\mathbf{F}_{\text {hitung }}$ & $\mathbf{F}_{\text {tabel }}$ & $\begin{array}{c}\text { Keputusan } \\
\text { statistik }\end{array}$ & Korelasi & $\begin{array}{c}\text { Keputusan } \\
\text { akhir }\end{array}$ \\
\hline $\mathrm{H}_{0}$ & - & 4,543 & - & - & $\mathrm{H}_{0}$ diterima \\
$\mathrm{H}_{\mathrm{a}}$ & 1,574 & 4,543 & Tidak Sig. & $\begin{array}{c}\text { Tidak ada } \\
\text { pengaruh }\end{array}$ & \begin{tabular}{c}
$\mathrm{H}_{\mathrm{a}}$ ditolak \\
\hline
\end{tabular} \\
\hline
\end{tabular}

\section{Menghitung Efektifitas Garis Regresi (EGR)}

Efektifitas Garis Regresi (EGR) adalah garis yang menunjukkan berapa garis regresi yang dapat digunakan untuk mengetahui berapa persen $(\%)$ pengaruh variabel $(\mathrm{X})$ terhadap variabel $\left(\mathrm{Y}_{1}\right)$ dan $\left(\mathrm{Y}_{2}\right)$. Adapun rumusnya sebagai berikut:

Efektifitas Garis Regresi $(E G R)=\frac{J K_{\text {reg }}}{J K_{\text {total }}} \times 100 \%$ 
a. Menghitung pengaruh media pembelajaran audio-visual dengan microsoft powerpoint $(\mathrm{X})$ terhadap keaktifan belajar siswa $\left(\mathrm{Y}_{1}\right)$.

$$
\begin{gathered}
J K_{\text {total }}=\sum Y_{1}^{2}-\frac{\left(\sum Y_{1}\right)^{2}}{N} \text { dengan hasil } J K_{\text {total }}=1,025 \\
I K_{\text {reg }}=b_{1}\left(\sum X Y_{1}\right)+a_{1}\left(\sum Y_{1}\right)-\frac{\left(\sum Y_{1}\right)^{2}}{N} \text { dengan hasil }(E G R) \\
=\frac{0,822}{1,025} \times 100 \%
\end{gathered}
$$

$$
E G R=80,195 \%
$$

b. Menghitung pengaruh media pembelajaran audio-visual dengan microsoft powerpoint $(\mathrm{X})$ terhadap pemahaman belajar siswa $\left(\mathrm{Y}_{2}\right)$.

$$
\begin{aligned}
& I K_{\text {total }}=\sum Y_{2}^{2}-\frac{\left(\sum Y_{2}\right)^{2}}{N} \text { dengan hasil } J K_{\text {total }}=96,236 \\
& I K_{\text {reg }}=b_{2}\left(\sum X Y_{2}\right)+a_{2}\left(\sum Y_{2}\right)-\frac{\left(\sum Y_{2}\right)^{2}}{N} \text { dengan hasil } J K_{\text {reg }}=2496326 \\
& (E G R)=\frac{J K_{\text {reg }}}{J K_{\text {total }}} \times 100 \% \\
& (E G R)=\frac{2.496,326}{96,236} \times 100 \% \\
& E G R=25,939 \%
\end{aligned}
$$

\section{Pengujian Hipotesis}

1. Menghitung pengaruh media pembelajaran audio-visual dengan microsoft powerpoint $(\mathbf{X})$ terhadap keaktifan belajar siswa $\left(\mathbf{Y}_{1}\right)$.

Untuk mengetahui sejauh mana pengaruh peggunaan media pembelajaran audio-visual dengan microsoft powerpoint $(\mathrm{X})$ terhadap keaktifan belajar siswa (Y) pada kelas X IPS 2 (Kelas Eksperimen) dan kelas X IPS 1 (Kelas Konrol), maka dapat dihitung dengan menghitung korelasi antar variabel $(\mathrm{X})$ dan $\left(\mathrm{Y}_{1}\right)$. Dari hasil perhitungan diperoleh nilai $r_{x y}$ sebesar $(6,234)$ untuk kelas X IPS 2 (Kelas Eksperimen), sedangkan hasil perhitungan untuk kelas X IPS 1 (Kelas Kontrol) diperoleh nilai $r_{x y}$ sebesar $(-0,099)$.

Dan Pada kelas X IPS 2 (Kelas Eksperimen) di peroleh $r_{\text {tabel }}=0,482$ dengan $\mathrm{r}_{\text {hitung }}=6,234$, sedangkan kelas X IPS 1 (Kelas Kontrol) di peroleh $\mathrm{r}_{\text {tabel }}=0,514$ dengan $r_{\text {hitung }}=(-0,099)$.

Pada kelas X IPS 2 (Kelas Eksperimen) di peroleh hasil perbandingan $\mathbf{r}_{\text {hitung }}$ $>\mathrm{r}_{\text {tabel }}$, artinya hipotesis kerja $\left(\mathrm{H}_{\mathrm{a}}\right)$ diterima dan hipotesis nihil $\left(\mathrm{H}_{0}\right)$ ditolak. Yang berarti "Ada pengaruh media pembelajaran audio-visual dengan microsoft powerpoint $(\mathrm{X})$ terhadap Pemahaman belajar siswa $\left(\mathrm{Y}_{1}\right)$ kelas X IPS 2 di MA NU Islamiyah Asembagus". 
Sedangkan kelas X IPS 1 (Kelas Kontrol) di peroleh hasil perbandingan $\mathrm{r}_{\text {hitung }}<\mathrm{r}_{\text {tabel }}$, artinya hipotesis kerja $\left(\mathrm{H}_{\mathrm{a}}\right)$ ditolak dan hipotesis nihil $\left(\mathrm{H}_{0}\right)$ diterima. Yang artinya "Tidak ada pengaruh media pembelajaran audio-visual dengan microsoft powerpoint $(\mathrm{X})$ terhadap Pemahaman belajar siswa $\left(\mathrm{Y}_{1}\right)$ kelas X IPS 2 di MA NU Islamiyah Asembagus".

Setelah dilihat pada tabel interprestasi koefisien korelasi diketahui bahwa nilai kelas X IPS 2 (Kelas Eksperimen) sebasar $(6,234)$ terletak antara + 0,81 s/d + 1,00 yang berarti tingkat pengaruh sempurna. Sedangkan pađa kelas X IPS 1 (Kelas Kontrol) dengan nilai sebesar $(-0,099)$ terletak antara $+0,00 \mathrm{~s} / \mathrm{d}+0,20$ yang berarti tidak ada pengaruh.

\section{Menghitung pengaruh media pembelajaran audio-visual dengan microsoft powerpoint $(\mathrm{X})$ terhadap pemahaman belajar siswa $\left(\mathrm{Y}_{2}\right)$.}

Untuk mengetahui sejauh mana pengaruh peggunaan media pembelajaran audio-visual dengan microsoft powerpoint (X) terhadap pemahaman belajar siswa $\left(\mathrm{Y}_{2}\right)$ pada kelas X IPS 2 (Kelas Eksperimen) dan kelas X IPS 1 (Kelas Konrol), maka dapat dihitung dengan menghitung korelasi antar variabel $(\mathrm{X})$ dan $\left(\mathrm{Y}_{2}\right)$. Dari hasil perhitungan diperoleh nilai $r_{x y}$ sebesar $(0,584)$ untuk kelas X IPS 2 (Kelas Eksperimen), sedangkan hasil perhitungan untuk kelas X IPS 1 (Kelas Kontrol) diperoleh nilai $\mathrm{r}_{\mathrm{xy}}$ sebesar $(0,309)$

Pada kelas X IPS 2 (Kelas Eksperimen) di peroleh $r_{\text {tabel }}=(0,482)$ dengan $r_{\text {hitung }}=(0,584)$, sedangkan kelas X IPS 1 (Kelas Kontrol) di peroleh $r_{\text {tabel }}=0,514$ dengan $r_{\text {hitung }}=(0,309)$. Sedangkan pada kelas X IPS 2 (Kelas Eksperimen) di peroleh hasil perbandingan $r_{\text {hitung }}>r_{\text {tabel }}$, artinya hipotesis kerja $\left(\mathrm{H}_{\mathrm{a}}\right)$ diterima dan hipotesis nihil $\left(\mathrm{H}_{0}\right)$ ditolak. Yang berarti "Ada pengaruh media pembelajaran audio-visual dengan microsoft powerpoint $(\mathrm{X})$ terhadap pemahaman belajar siswa $\left(\mathrm{Y}_{2}\right)$ kelas X IPS 2 di MA NU Islamiyah Asembagus".

Sedangkan kelas X IPS 1 (Kelas Kontrol) di peroleh hasil perbandingan $\mathrm{r}_{\text {hitung }}<\mathrm{r}_{\text {tabel }}$, artinya hipotesis kerja $\left(\mathrm{H}_{\mathrm{a}}\right)$ ditolak dan hipotesis nihil $\left(\mathrm{H}_{0}\right)$ diterima. Yang artinya "Tidak ada pengaruh media pembelajaran audio-visual dengan microsoft powerpoint $(\mathrm{X})$ terhadap pemahaman belajar siswa $\left(\mathrm{Y}_{2}\right)$ kelas X IPS 2 di MA NU Islamiyah".

Dari nilai tersebut dapat dilihat pada tabel interprestasi koefisien korelasi :

Setelah dilihat pada tabel interprestasi oefisien korelasi diketahui bahwa nilai kelas X IPS 2 (Kelas Eksperimen) sebasar $(0,584)$ terletak antara + 0,41 s/d + 0,60 yang berarti tingkat pengaruh sedang. Sedangkan padā kelas X IPS 1 (Kelas Kontrol) dengan nilai sebesar $(0,309)$ terletak antara $+0,21 \mathrm{~s} / \mathrm{d}+0,40$ yang berarti tingkat pengaruh rendah. 


\section{PEMBAHASAN}

1. Menghitung pengaruh media pembelajaran audio-visual dengan microsoft powerpoint $(\mathrm{X})$ terhadap keaktifan belajar siswa $\left(\mathrm{Y}_{1}\right)$.

Setelah menganalisa data dan pengujian hipotesis, diketahui tingkat nilai koefisien koelasi antara pengaruh media pembelajaran audio-visual dengan microsoft powerpoint $(\mathrm{X})$ terhadap Pemahaman belajar siswa $\left(\mathrm{Y}_{1}\right)$ pada kelas (Kelas Eksperimen) sebesar 6,234 dengan nilai $F_{\text {hitung }}=17,004$. Untuk mengetahui signifikan atau tidaknya nilai $F_{\text {hitung }}$ dibandingkan dengan nilai $F_{\text {tabel. }}$. Derajat kebebasan untuk menguji signifikan nilai $F_{\text {hitung }}$ adalah $\mathrm{m}$ $(\mathrm{N}-\mathrm{m}-1)$ dengan $\mathrm{db}=1 / 17$, nilai $\mathrm{F}_{\text {tabel }}$ dengan taraf signifikan $5 \%=4,451$ dengan nilai $F_{\text {hitung }}=17,004$ ini signifikan dengan Efektifitas Garis Regresi (EGR) sebesar $=30,993 \%$.

Sedangkan untuk (kelas kontrol) diketahui tingkat nilai koefisien kelasi antara pengaruh media pembelajaran audio-visual dengan microsoft powerpoint $(\mathrm{X})$ terhadap keaktifan belajar siswa $\left(\mathrm{Y}_{1}\right)$ sebesar -0,099 dengan nilai $F_{\text {hitung }}=0,136$. Untuk mengetahui signifikan atau tidaknya nilai $F_{\text {hitung }}$ dibandingkan dengan nilai $F_{\text {tabel }}$. Derajat kebebasan untuk menguji signifikan nilai $\mathrm{F}_{\text {hitung }}$ adalah $\mathrm{m}(\mathrm{N}-\mathrm{m}-1)$ dengan $\mathrm{db}=1 / 15$, nilai $\mathrm{F}_{\text {tabel }}$ dengan taraf signifikan $5 \%=4,543$ dengan nilai $F_{\text {hitung }}=0,136$ ini tidak signifikan dengan Efektifitas Garis Regresi (EGR) sebesar $=80,195 \%$.

\section{Menghitung pengaruh media pembelajaran audio-visual dengan microsoft powerpoint $(\mathrm{X})$ terhadap pemahaman belajar siswa $\left(\mathbf{Y}_{2}\right)$.}

Setelah menganalisa data dan pengujian hipotesis, diketahui tingkat nilai koefisien koelasi antara pengaruh media pembelajaran audio-visual dengan microsoft powerpoint $(\mathrm{X})$ terhadap pemahaman belajar siswa $\left(\mathrm{Y}_{2}\right)$ pada kelas (Kelas Eksperimen) sebesar 0,584 dengan nilai $F_{\text {hitung }}=8,796$. Untuk mengetahui signifikan atau tidaknya nilai $F_{\text {hitung }}$ dibandingkan dengan nilai $F_{\text {tabel }}$. Derajat kebebasan untuk menguji signifikan nilai $F_{\text {hitung }}$ adalah $\mathrm{m}$ $(\mathrm{N}-\mathrm{m}-1)$ dengan $\mathrm{db}=1 / 17$, nilai $\mathrm{F}_{\text {tabel }}$ dengan taraf signifikan $5 \%=4,451$ dengan nilai $F_{\text {hitung }}=8,796$ ini signifikan dengan Efektifitas Garis Regresi (EGR) sebesar $=13,71 \%$.

Sedangkan untuk (kelas kontrol) diketahui tingkat nilai koefisien koelasi antara pengaruh media pembelajaran audio-visual dengan microsoft powerpoint $(\mathrm{X})$ terhadap pemahaman belajar siswa $\left(\mathrm{Y}_{2}\right)$ sebesar 0,309 dengan nilai $F_{\text {hitung }}=1,574$. Untuk mengetahui signifikan atau tidaknya nilai

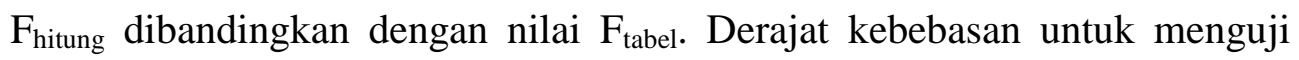
signifikan nilai $\mathrm{F}_{\text {hitung }}$ adalah $\mathrm{m}(\mathrm{N}-\mathrm{m}-1)$ dengan $\mathrm{db}=1 / 15$, nilai $\mathrm{F}_{\text {tabel }}$ dengan taraf signifikan $5 \%=4,543$ dengan nilai $F_{\text {hitung }}=1,574$ ini tidak signifikan dengan Efektifitas Garis Regresi (EGR) sebesar $=25,939 \%$. 


\section{SARAN}

Dari hasil penelitian ini, menunjukkan bahwa ada pengaruh penggunaan media pembelajaran audio-visual dengan microsoft powerpoint (X) terhadap Pemahaman belajar siswa $\left(\mathrm{Y}_{1}\right)$ kelas $\mathrm{X}$ pada mata pelajaran sosiologi di MA NU Islamiyah Asembagus tahun pelajaran2019-2020, diketahui bahwa nilai kelas X IPS 2 (Kelas Eksperimen) sebasar $(6,234)$ dengan tingkat pengaruh sempurna. Dan ada pengaruh penggunaan media pembelajaran audio-visual dengan microsoft powerpoint $(\mathrm{X})$ terhadap pemahaman belajar siswa $\left(\mathrm{Y}_{2}\right)$ kelas $\mathrm{X}$ pada mata pelajaran sosiologi di MA NU Islamiyah Asembagus, dan diketahui bahwa nilai kelas X IPS 2 (Kelas Eksperimen) sebasar $(0,584)$ dengan tingkat pengaruh sedang. Sedangkan pada kelas X IPS 1 (Kelas Kontrol) dengan nilai sebesar $(0,309)$ dengan tingkat pengaruh rendah.

\section{DAFTAR PUSTAKA}

Aprida Pane dan Muhammad Darwis Dasopang, 2017, BELAJAR-DANPELAJARAN,e-ISSN:2460-2345,p-ISSN:2442-6997: google scholar

Sugiono, 2018,Metode-Penelian-Kuantitatif-Kualitatid-dan-R\&D, Bandung: PT Alfabeta. 